\title{
The Issue of Official Religions and The Need for Multicultural Policy in Indonesia
}

\author{
Bowo Sugiarto ${ }^{1}$, Novia Anggarina Hapsari² \\ ${ }^{1}$ Department of Political Science, Jenderal Soedirman University \\ (bowosugiarto@gmail.com) \\ ${ }^{2}$ Department of Political Science, Jenderal Soedirman University
}

\begin{abstract}
Examining the problem within the discourse on official religions and the religious discrimination has been experienced by The Baduy Luar tribe in the obtaining of identity card (Kartu Tanda Penduduk), this paper proposes an argument of the need for more multicultural policy in Indonesia. The discrimination which has been experienced by the members of The Baduy Luar tribe is that they cannot list their religion, Sunda Wiwitan, in their identity cards since it is considered not a religion. Revisiting the regulations which has given contribution to the discourse on official religions in Indonesia, this article argues that the notion of official religions apparently does not have a strong legal basis. Therefore, the identity card policy in the postNew Order Indonesia has been established based on a fragile and problematic foundation. Based on Kymlicka's theory of multiculturalism, this paper concludes that the members of Baduy Luar have a legitimate reason to list their religion in their identity cards.
\end{abstract}

Keywords: identity card; multicultural policy; official religions; Baduy Luar tribe.

\section{Introduction}

In the context of religious studies, scholars of this field share the same opinion about the definition of religion. They agree that defining religion is not an easy task because its definition is complicated or even contested. Even though some might say that religion can be found almost in every society, yet they have disagreed about the definition of religion due to their cultural background (Nye, 2004, Rodriguez \& Harding, 2009). Therefore, we can suppose that its definition is multivocal rather than singular. Unfortunately, the possibility of various definitions of religion may give disadvantages for minority when it turns to the political realm. This paper examines the problem resulted from the government's attempt to define religion in Indonesia. The paper's discussion will look into the identity card policy as experienced by Baduy Tribe in order to disentangle the problem within the idea of recognized and unrecognized religions in Indonesia politics. The differentiation between recognized/official and unrecognized/unofficial religions in Indonesia has had unexpected effects for religious and cultural minority groups like Baduy Tribe. One of the unexpected effects which will be the focus this paper is that they are not allowed to list their religions in their identity cards. The identity card policy will be scrutinized in the perspective of multiculturalism theory.

\section{Research Method}

The research was conducted through qualitative method. The research focus on the case of identity card policy has been experienced by Baduy Luar people. The data were collected through document analyses and in depth interviews. In document analyses, we analyzed relevant documents such as official documents, significant references, and the 
media. In indepth interview, we gathered data from government officials and Baduy Luar people.

\section{Discussion}

\subsection{Baduy Tribe}

Baduy Tribe lives in the remote highland jungle of Mount Kendeng in which administratively belong to Kanekes Village, Banten Province. The economic activities of Baduy people are mostly in the form of agriculture because farming is considered as part of their religious practices. The Baduy Tribe consist of two big groups who exist in two different locations, i.e. Baduy Dalam (The Inner Baduy) and Baduy Luar (The Outer Baduy). The main difference between the two groups is related to the degree of the communities in responding the cultural influences of modern lifestyle. The Baduy Dalam people strictly follow their customs and religious belief and reject the influence of modern culture. Meanwhile, the Baduy Luar people relatively accept influences from the outsider, especially which are related to modern tools. Although Baduy Luar relatively accept modern tools, but they remain have held the Baduy's traditional customs and religion.

Baduy Tribe practice two different systems of administration, i.e. traditional administration and national administration. The traditional administration is implemented based on Baduy's customs and religious belief, whereas the national administration is applied based on Indonesia constitution and legal system. Basically, the national administration is subordinated to traditional administration, thus, the policy made by the national administration could not be contravened Baduy's customs and religious belief. Baduy's customs mostly rely on their religious belief called Sunda Wiwitan. It is derived from two words, i.e. Sunda and Wiwitan. Sunda is the name of an ethnic group who mostly live in the western part of the Java island. The word Wiwitan means origin or original. Thus, Sunda Wiwitan means the original Sunda (Indrawardana, 2011). The teaching of Sunda Wiwitan believes in God called Gusti Allah $^{(1)}$ and the prophet namely Adam Tunggal. The teaching of this religious belief is not codified into holy book, but it is transmitted from generation to generation in the form of proverbs. Different with other religions like Islam that requires daily worship, Sunda Wiwitan teaching is practiced through daily activities and religious rituals which purposefully to honor the ancestors and sanctify the environment or the earth (Wahid, 2010). Since Sunda Wiwitan is counted as a form of religious syncretism, thus the outsiders consider it as not a religion.

\footnotetext{
(1) The God in Sunda Wiwitan is also called Batara Tunggal, Batara Jagad and Batara Seda Niskala.
} 


\subsection{Defining Religion, Regulating Religion}

The notion of official religions firstly emerged in Indonesia in 1952 when the Minister of Religion proposed minimum requirements for a religion in order to be recognized by the government. The requirements were that the religion should: has a prophet, has a holy scripture, and internationally recognized (Subagya, 1988: 27). Unfortunately, the definition could not last long because the Balinese Hindus were resistant to it (Tolkhah, 2001: 43). In 1961, the Ministry of Religion proposed a new definition of religion. According to this definition, a religion should have a holy scripture, a prophet, The Authotitative of The One and Only God, and a system of law (Mulder, 2005: 24). Nevertheless, the definition had never been legalized as a regulation. The dominant discourse on official religions found its definite form when the government introduced the Law No. 1/PNPS/1965 on the Prevention of Blasphemy and Abuse of Religion. The regulation does not mention a category of recognized religions or official religions explicitly. However, many people use the law as a foundation for categorizing religions into recognized and unrecognized religions. The law which follows the logical framework of the Law No. 1/PNPS/1965 is the Minister of Home Affair's Circulation Letter No. 774/74054/1978 on the guidance for registering religions in the identity card (KTP). According to the Circulation Letter, there were five recognized religions in Indonesia, i.e. Islam, Christian, Catholic, Hindu and Budha. The legacy of the Circulation Letter has been continued by the Law No. 23/2006 on the Administration of Population Affairs. This regulation does indeed not mentioned explicitly about the recognized religions in Indonesia, yet it states clearly that kepercayaan (belief) is not a religion. In addition, the technical instruction on the making of identity card which is based on the EKTP application system only mentions six religions, i.e. Islam, Christian, Catholic, Hindu, Budha and Konghucu. Under this Law, if people's religion does not belong to the recognized religions, he or she can leave the religion column blank or chose to be registered as the adherents of kepercayaan.

This paper argues that the regulations which has defined religions and has caused discrimination over the adherents of unrecognized religions unfortunately based on problematic and vulnerable logic. The Law No. 1/PNPS/1965, the Minister of Home Affairs' Circulation Letter No. 774/74054/1978 and the Law No. 23/2006 should refer to the constitution, i.e. UUD 1945. According to the article 28 and 29 of the amended version of UUD 1945, every person has the right to freedom of religion. The constitution which should be a 
reference for many regulations actually does not mention the term of recognized or official religion in Indonesia. The encouragements of the freedom of religion in Indonesia are also mentioned in at least two laws, i.e. the Law No. 39/1999 on Human Rights and the Law No. 12/2005 on the Ratification of the International Covenant of the Political and Civil Rights. If religion is one of the basic rights which should be guaranteed by the state, then the indication of the recognized religions or the official religions should be found in the constitution (Rahmah \& Sudrajat, 2009). Therefore, the distinction between the recognized religions and the unrecognized religions/beliefs which has been implemented in the application system of E-KTP has not a strong legal basis.

\subsection{The Baduy Luar's Experience}

The prohibition to list unrecognized religion in identity card in the Indonesian context may bring a serious matter because "if the religion column is left blank, the holder of the identity card may be accused of being an atheist" (Arifin, 2010: 32). The specific experiences of the Baduy Luar community regarding the problem of their religion's registration in their identity cards which will be shown bellow confirms the negative effect of the idea of recognized religions. The Civil Registry Office had offered Baduy's people to list kepercayaan in the religion column of their identity cards, but they refused it. They insisted that Sunda Wiwitan is a religion, rather than a form of kepercayaan. In their view, kepercayaan has a negative connotation since it considered as synonymous with animism. They claim that Sunda Wiwitan and other religions shares common features such as believe in and worship God. Besides, they have a will to live and die as the Sunda Wiwitan adherents. According to Sunda Wiwitan teaching, the funeral ceremony of the dead should be done by following certain ritual and the dead have to be buried in Kanekes Village. In this view, the registration of their religion in identity card means the signify when they travel to the outer world, that they are adherents of Sunda Wiwitan. Thus, when a Baduy people travels to another region and die suddenly in an accident at the region, then other people can recognize the dead by the identity card. So that, the dead can be taken care of by following the Sunda Wiwitan teaching. Actually, between early 1970's and 2010, the Baduy Luar community was allowed to list Sunda Wiwitan in their identity cards. It can be assumed that this phenomenon happened because of the discretion of the local government that willing to accommodate Baduy's aspiration. The change has happened since 2010, with reference to the Presidential Regulation No. 35/2010, the making of identity card should be done with the technical 
instruction that applied nationwide. Based on the regulation, the making of identity card uses the EKTP (Electronic-Identity Card) application system. In this application system, we cannot list a name of religion in the religion column manually, but we have to chose a name of religion from the list provided by the application system. Baduy people reject the new regulation of identity card making because they are not allowed to list their religion in their identity cards. Yet they agreed to follow the new identity card making procedure after they have been told that the Civil Registry Office will consult their aspiration to the highest authority. Unfortunately, the Ministry of Home Affairs' respond is still based on the regulations that has given disadvantages to Baduy people.

\subsection{Multicultural Policy}

This paper argues that the distinction between recognized and unrecognized religions that has created discrimination in favor of citizen's religious belief in the context of identity card making in Indonesia is based on a vulnerable legal basis. In order to propose a solution for the problematic identity card policy in Indonesia, this paper develops argument based on Will Kymlicka's theory on multiculturalism. Kymlicka reaffirms his position on multiculturalism theory by explaining that it is "first and foremost about developing new models of democratic citizenship, grounded in human-rights ideals, to replace earlier uncivil and undemocratic relations of hierarchy and exclusion" (Kymlicka, 2012: 8). In this perspective, multicultural policycanbe understoodas an attempt to open upaccess for cultural minorities to economic and political opportunities. Kymlicka suggests that a liberal democratic state should accommodate national minority and ethnic group's demands even though it has to give differential treatments to their differential needs (Kymlicka, 1995).

This paper suggests that the implementation of multicultural policy to accommodate the minority culture like Baduy Tribe should be comprehensive. The local government of Lebak has introduced a law that guarantees Baduy Tribe's community land (tanah ulayat) to be preserved and utilized according to Baduy's customs. Moreover, Baduy people are allowed to practice their own traditional administration side by side with the national administration. Unfortunately, in the context of one of basic rights, that is freedom of religion, they are treated by discriminatory way. Indeed, Baduy people free to practice their religion, yet they cannot list their religion in their identity cards. This situation shows that the government's policies toward religious and ethnic diversity are inconsistent and failed. This paper suggests the government to implement a comprehensive 
multicultural policy toward identity card policy in Indonesia. This new policy is based on an assumption that all citizens should be treated equally. It means, the state should embrace religious diversity rather than try to define religion or to distinguish between recognized or unrecognized religions. By so doing, the state takes an affirmative action for disadvantages and minority religious communities. In this perspective, Baduy Tribe has belonged to the disadvantages and minority religious communities because of they are less in number and have lack of access to the formal political structure. Therefore, Baduy Tribe and other traditional community may list their religion in their identity cards.

\section{Conclusion}

The implementation of the politics of multiculturalism in a country needs an institutional arrangement that reconciles both the demands of diversity and unity. Equal treatment of cultural differences sometime has consequences of an institutional arrangement that ensures different treatments for different needs. The significance of different treatment also important in the context of realizing the same rights and opportunity for the disadvantages and minority groups. Religion as one of sources of disagreement should be a part of these institutional arrangement. Thus, the equality principle and the protection of the disadvantages and the minority groups' rights should also be a foundation of the religion-state relation in the multicultural society. Therefore, a multicultural policy should be implemented comprehensively in the sense that we could not say it guarantees the preservation of minority culture when at the same time it did not recognize citizens' basic rights. In the context identity card policy in Indonesia, the violation of Baduy Tribe's religious right and other religious minority groups can be avoided by disengaging the state from attempting to define religion.

\section{References}

1) Arifin, Syamsul. (2010). Attitudes to Human Rights and Freedom of Religion or Belief in Indonesia. Yogyakarta: Kanisius,.

2) Indrawardana, Ira. (2011). Sunda Wiwitan dalam Dinamika Zaman. Bandung: Yayasan Kebudayaan Rancage

3) Kymlicka, Will. (1995). Multicultural Citizenship. A Liberal Theory of Minority Rights. Oxford: Oxford University Press

4) .(2012).Multiculturalism:

Success, Failure and the Future. Washington DC: Migration Policy Institute,.

5) Mulder, Niels. (2005). Mysticism in Java. Ideology in Indonesia. Yogyakarta: Kanisius, 
6) Nye, Malory. (2004). Religion. The Basics. 2nd. Oxford: Routledge

7) Rahmah, Alef Musyahadah and Tedi Sudrajat. (2009). Penemuan Hukum In Concreto Dalam kebebasan Beragama dan Berkeyakinan. Jurnal Dinamika Hukum, 9 (2), 95-102

8) Rodriguez, Hillary and John S. Harding. (2009). Introduction to the Study of Religion. Oxford: Routledge

9) Subagya, Rahmat. (1988). Kepercayaan, Kebatinan, Kerohanian, Kejiwaan dan Agama. Yogyakarta: Kanisius

10) Tolkhah, Imam. (2001) Anatomi Konflik Politik di Indonesia: Belajar dari Ketegangan Politik Varian di Madukoro. Jakarta: Rajawali Press.

11)Wahid, Masykur. (2010). Sunda Wiwitan Baduy: Agama Penjaga Alam Lindung di Desa Kanekes Banten. Banjarmasin: The $10^{\text {th }}$ Annual Conference of Islamic Studies (ACIS) 